\title{
The Influence of Marketing Mix on Customer Purchasing Decision at The Abraham and Smith Restaurant
}

\author{
Ali Adhiansyah, Mochamad Whilky Rizkyanfi \\ Indonesia University of Education, Jl. Dr. Setiabudhi No. 229, Bandung 40154, Indonesia \\ *Corresponding Author E-mail: ali.adhiansyah@student.upi.edu
}

\begin{abstract}
The background of this research is based on the stagnant sales data of Abraham and Smith. This study aims to determine the effect of the marketing mix on consumer buying decisions in Abraham and Smith. This research is a quantitative research, using statistical-descriptive and verificative methods of analysis, which describe and define the influence of the independent variable $(\mathrm{X})$, namely the marketing mix (product, price, promotion, location, people, physical evidence, and process) on the dependent variable (Y), namely consumer buying decisions. This study employs the multiple linear regression analysis. Respondents of this study were 111 Abraham and Smith consumers, selected through accidental sampling technique. The results of this study show that the marketing mix, which has a significant effect on Abraham and Smith's consumer purchasing decisions, are product, place, and physical evidence. The conclusion of this research is that the variables of product, place, and physical evidence have a significant influence on consumer purchasing decisions. For further research, it is recommended to dig deeper into product variables, place, and physical evidence.
\end{abstract}

Keywords: $\quad$ Marketing Mix; Purchasing Decision; Restaurant.

First Received: July $2020 \quad$ Revised: August $2020 \quad$ Accepted: September 2020




\section{Introduction}

The food \& beverage industry sector plays an important role in the economy of Bandung. Business growth in the food \& beverage sector in Bandung will continue to grow along with the rising number of tourists that visit Bandung.

Abraham and Smith is a restaurant in Bandung located at Jalan Tamblong Dalam No. 2 and was founded in 2015. Abraham and Smith is a restaurant with a cafe type, emphasizing the theme of cooking \& culture.

Sales at Abraham and Smith can be said to be stagnant, as after five years of existence, it has not achieved a significant increase in terms of income. One that can influence the consumer purchasing decision process is the marketing mix (Sangadji \& Sopiah, 2013). Corresponding to the problem, the authors aims to conduct a further research in Abraham and Smith to find out the effect of the marketing mix on the consumer purchasing decisions.

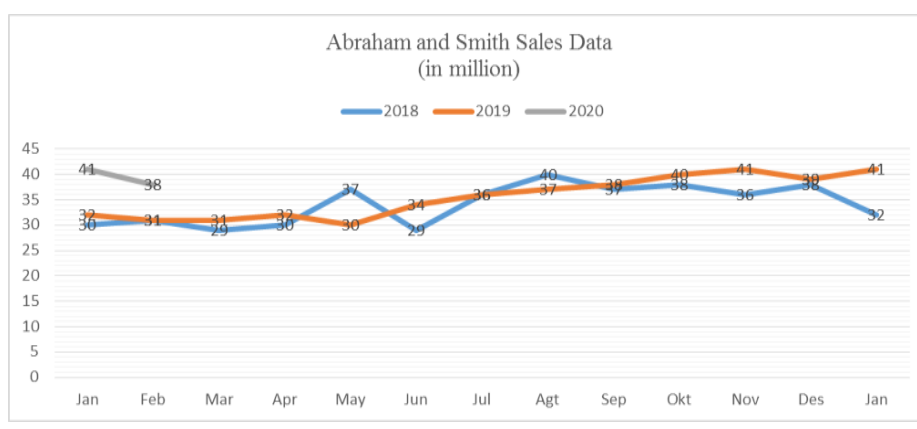

Figure 1. Abraham and Smith Sales Data for the Period of January 2018 - February 2020

Figure 1 shows the sales data of Abraham and Smith from 2018 to 2020 that experienced an increase and decrease in each month. Sales at Abraham and Smith have increased significantly in certain months, especially during the university mid-semesters and tend to decline at the end and beginning of the year precisely in the semester holiday.

\section{Literature Review}

\subsection{Marketing Mix}

Marketing mix is a marketing tool that companies use to achieve the company's goals. The marketing mix consists of product, price, promotion, and distribution, Sales at Abraham and Smith can be said to be stagnant, as after five years of existence, it has not achieved a significant increase in terms of income. One that can influence the consumer purchasing decision process is the marketing mix (Sangadji \& Sopiah, 2013). Corresponding to the problem, the authors aims to conduct a further research in Abraham and Smith to find out the effect of the marketing mix on the consumer purchasing decisions.

The following are sales data from Abraham and Smith. Which has the function of determining the achievement of marketing success, aiming to get a response from the target market (Kotler and Keller, 2007).

Hurriyati (2010) describes the concept of a traditional marketing mix which consists of 4Ps, namely product, price, place, and promotion. Meanwhile, for service marketing, it is necessary to expand the mix by adding elements of the nontraditional marketing mix, namely people, physical facilities (physical evidence), and processes so that they become the seven elements of the marketing mix (7P).

Based on the explanation above, it can be concluded that the marketing mix is a marketing tool intended by the company as a mean to achieve company goals.

\subsection{Product}

Rachmawati (2011) explains that a product is an overall concept object, or a process that provides benefits to consumers. Products in the culinary business depend heavily on experience. A product can be a complete package consisting of food, drink, service, atmosphere, and comfort, which satisfies the needs and desires of consumers, and creates an unforgettable impression. 
Diners at restaurants pay for the total dining experience, not just for the food.

\subsection{Price}

Tjiptono (2000) explains that, price is a monetary unit, or a measure of goods and services that are exchanged to obtain ownership rights or use of goods and services.

Engel, J; Blackwell R (2004) explains that price is an amount of money which is used to get a number of combinations of products and services.

From the above definition it is concluded that the price is, the nominal paid by the buyer for the products and services provided by the seller.

\subsection{Location}

Hurriyati (2010) explains that location can be defined as the distribution of products to consumers, while for the service industry, location is defined as a place where services occur.

Tjiptono (1996) explains that location determines the success of a company as it is related to a company's potential market, strategic dimensions, such as flexibility, competitive, positioning, and focus. The flexibility of a location is a measure of the extent to which a company can react to changes in the economic situation.

From the above explanation it can be concluded that location is a place where services occur and also determines the success of the company.

\subsection{Promotion}

Hurriyati (2010) describes that promotion is a determining factor for the success of a marketing goal. Regardless of the quality of a product offered, if consumers have never heard of it and are not sure if it will be useful to them, they will not buy it.

Tjiptono (2007) explains that promotion is a form of marketing communication to spread information, influence or persuade, and increase the target market to be willing to accept, buy, and be loyal to the products offered by the company concerned.

Thus, it is concluded that promotion is a tool used to disseminate information to achieve marketing success.

\subsection{People}

Hurriyati (2010) explained that People are actors who have a role in service delivery, so that they can influence buyers' perceptions. The people in question are company employees, consumers, and other consumers in the service environment

Lupiyoadi (2013) stated that there are four roles from the people aspect that influence customers, namely: Contractors: interacting directly with consumers in a fairly recurrent frequency and greatly influencing consumer decisions in buying products. Modifier: not directly affecting consumers, but quite often dealing with consumers, for example: receptionist. Influencers: influencing consumers in the decision to buy, but not directly related to consumers. Isolated: do not directly participate in marketing and also do not meet customers often, for example: sales administration employees.

From the explanation above, it can be concluded that people are actors who have a role in marketing to achieve company goals.

\subsection{Physical Evidence}

Hurriyati (2010) considers physical facilities can significantly influence consumer decisions. The physical facilities include physical buildings, tools, equipment, logos, colors, and other items.

\subsection{Process}

Lupiyoadi (2013) identifies that there are two ways in the process, the first is Complexity: things that are related to the steps of a process. Nrxt is Divergence: a change in step by step process. The process reflects how all elements of the marketing mix can be coordinated to ensure the quality and consistency of a product delivered to 
customers.

\subsection{Purchasing Decision}

Setiadi (2003: 413) pointed out that a purchasing decision is a decision that involves two or more choices of products or services to make a purchase.

Kotler \& Keller (2016) further explained that purchasing decisions are evaluation stage in which consumers will make priorities between brands in a collection of choices that consumers like.

To be brief, a purchasing decision is a decision made by consumers to choose a product from a variety of choices and will form the priority of a set of choices.

\subsection{Purchasing Decision Process}

Kotler \& Keller (2009) mentioned that the purchasing decision making process is developed into five stages, namely:

a. Problem recognition. It starts when the buyer finds a problem for his needs;

b. Information search. It refers to a source of information for consumers that consists of four parts, namely private, commercial, public, and experimental. Through information gathering, consumers can learn about competitors.

c. Evaluation of alternatives. In this stage consumers make a comparison of different brands;

d. Purchase Decisions. It occurs when consumers make decisions to make purchases;

e. Postpurchase behavior. After buying a product, consumers will feel satisfied or not.

2.11 Factors that influence the Purchase Decisions

Kotler \& Keller (2009) highlighted several factors in purchasing decisions, namely product, brand, supplier selection, purchase time, purchase amount, payment method.

\subsection{Hypothesis}

Sugiyono (2008) explained that the hypothesis is a temporary answer to the formulation of research problems. Therefore, the formulation of research problems is usually arranged in the form of questions and is said to be temporary because the answers given are only based on relevant theories, not based on empirical facts by obtaining through data collection. Therefore, the hypothesis can also be stated as a theoretical answer to the formulation of the research problem, not an empirical answer.

Based on the facts in the research, the hypothesis is proposed as an alternative to be accepted or rejected. The hypotheses to be tested in this study are:

a. The marketing mix (7P) at Abraham and Smith is quite effective.

b. Consumer purchasing decisions at Abraham and Smith are quite good.

c. The marketing mix gives a positive impact on consumer purchasing decisions in Abraham and Smith.

\section{Materials and Methods}

\subsection{Research Objects and Subjects}

The object of this research is the marketing mix $(\mathrm{X})$ which includes products, prices, locations, promotions, people, physical facilities, and processes, as well as purchasing decisions (Y). The subjects of this research are Abraham and Smith's consumers.

\subsection{Methods}

The method used in this research are descriptive and verification statistical methods with quantitative research type.

The purpose of using this type of quantitative data is to determine the relationship of two or more variables which later produce a description of this research. 
3.3 Population and Sample

Tabel 1. Abraham and Smith Visitor Data

\begin{tabular}{lc}
\multicolumn{1}{c}{ for 2019} & \\
\hline \multicolumn{1}{c}{ Month } & Visitor \\
\hline January & 430 \\
February & 396 \\
March & 390 \\
April & 432 \\
May & 374 \\
June & 464 \\
July & 480 \\
August & 497 \\
September & 525 \\
October & 546 \\
November & 558 \\
December & 528 \\
$\quad$ Total & 5620 \\
\hline
\end{tabular}

Based on the data, there were 5620 visitors in the past year, with an average of 468 people visiting Abraham and Smith every month, and this number is taken as the population.

The following is the sample calculation using the Slovin formula:

$$
\begin{aligned}
\mathrm{n} & =\mathrm{N} /\left(1+\mathrm{N} \times \mathrm{e}^{\wedge} 2\right) \\
\mathrm{n} & =5620 /(1+5620 \times \llbracket(0,10)) \wedge 2)= \\
98,251 & =100
\end{aligned}
$$

Description:

$\mathrm{n}=$ sample size

$\mathrm{N}=$ population size

$\mathrm{e}=$ inaccurate allowance due to sample error which can be tolerated.

The inaccuracy allowance calculation in the Slovin formula is $10 \%$ or equal to 0.1 . Therefore, the sample of this study amounted to 100 samples.

\subsection{Data Collection Technique}

The technique used in this research is the distribution of questionnaires. It is done by giving a set of questions or written statements to respondents to be answered. The questionnaire is an efficient data collection technique, if the researcher knows exactly what variables to measure, and knows what to expect from the respondent (Sugiyono, 2008).

\subsection{Types and Sources of Data}

The data source used in this study is the primary data source. Primary data sources are data sources that directly provide data to researchers. To obtain this data, researchers can use data collection methods, such as surveys, observations, and interviews (Sugiyono, 2008).

The type of data used in this research is primary data, obtained directly from respondents as first-hand information (Wardiyanta, 2008).

\section{Results and Discussion}

\subsection{Respondent Data}

In brief, the respondents of Abraham and Smith are mostly female (65.8\%), with an age range of $21-30$ years (81\%), domiciled in Bandung (67.5\%), as students $(65,7 \%)$ and with an average monthly income of <IDR 2,500,000.00 (66.6\%).

\subsection{Respondents' Experience}

Regarding the experience of respondents, it is found out that 55 respondents knew Abraham and Smith from social media, 97 people had made purchases at Abraham and Smith previously, 97 people used private vehicles to come to Abraham and Smith, 62 people spent 1-2 hours at Abraham and Smith, and 88 people spend under Rp. 100,000.00 in one transaction at Abraham and Smith. 
Table 2. Recapitulation of Respondents' Response Results to the Marketing Mix in Abraham and Smith

\begin{tabular}{clcccc}
\hline No. & Dimensions & $\begin{array}{c}\text { Total } \\
\text { Score }\end{array}$ & $\begin{array}{c}\text { Number of } \\
\text { Statements }\end{array}$ & $\begin{array}{c}\text { Average } \\
\text { score }\end{array}$ & $\%$ \\
\hline 1. & Product & 1.172 & 3 & 390,7 & $15,1 \%$ \\
2. & Price & 725 & 2 & 362,5 & $9,4 \%$ \\
3. & Place & 1.192 & 3 & 397,3 & $15,4 \%$ \\
4. & Promotion & 698 & 2 & 349 & $9 \%$ \\
5. & People & 772 & 2 & 386 & $10 \%$ \\
6. & Physical evidence & 1.577 & 4 & 394,3 & $20,3 \%$ \\
7. & Process & 1616 & 4 & 404 & $20,8 \%$ \\
\hline \multicolumn{2}{l}{ TOTAL } & 7752 & 20 & 2683,8 & 100 \\
\hline
\end{tabular}

The table above shows the results of the recapitulation on the marketing mix variable, which was carried out on 111 respondents, and states that the total score is 7,752 or an average of 2,683.8.

Based on table 2, the highest score of Abraham and Smith's consumers is on the process dimension, which gets an average score of 404 or a percentage of $20.8 \%$, while the lowest value of the marketing mix is the promotion dimension which gets an average score of 349 or $9 \%$.

The total score of the Marketing Mix score is 7,752 , compared with the standard score criteria, which is obtained through the calculation of the ideal score and the smallest score, it can be seen that the continuum area which shows the ideal area is obtained through the following formula.

Maximum index value $=$ Highest score $\mathrm{x}$ Number of statements $x$ Number of respondents

$\begin{aligned} & =5 \times 20 \times 111 \\ & =11.100 \\ \text { Minimum index value } & =\text { Lowest score } \mathrm{x}\end{aligned}$

Number of statements $x$ Number of respondents

$$
\begin{aligned}
& =1 \times 20 \times 111 \\
& =2.220
\end{aligned}
$$

Variable level = Maximum index value Minimum index value

$$
\begin{aligned}
& =11.100-2.220 \\
& =8.880
\end{aligned}
$$

Variable range $=$ Variabel level $:$ Number of interval classes

$$
\begin{aligned}
& =8.880: 5 \\
& =1.776
\end{aligned}
$$

Score percentage $=($ total score $:$ maximum score) x $100 \%$

$$
\begin{aligned}
& =(7752: 11.100) \times 100 \% \\
& =69,8 \%
\end{aligned}
$$

The expected ideal score for respondents' answers about the Marketing

\begin{tabular}{|c|c|c|c|c|}
\hline $\begin{array}{l}\text { Very } \\
\text { Low }\end{array}$ & Low & $\begin{array}{l}\text { High } \\
\text { Enough }\end{array}$ & High & $\begin{array}{l}\text { Very } \\
\text { High }\end{array}$ \\
\hline & & & $\underset{7752}{\frac{1}{2}}$ & \\
\hline 2220 & 3996 & 5772 & 9324 & 11100 \\
\hline
\end{tabular}
Mix in Abraham and Smith for 20 statements is 11,100 . The calculation results obtained from a total score of 7,752 with a percentage of $69.8 \%$, this indicates an assessment made by Abraham and Smith's consumers. The following figure 1 is the result of the Marketing Mix continuum.

Figure 2 Continuum Line of Respondents' Responses to the Marketing Mix in Abraham and Smith

Based on the continuum line of Marketing Mix analysis, the responses fall into the "High" category. This shows that, 
the Marketing Mix gets high attention from Abraham and Smith's customers.

4.3 Respondents' Responses to The Purchasing Decisions

Respondents' responses to purchasing decisions can be measured from the following factors: product, brand, supplier selection, purchase time, purchase amount, payment method. The following table 3 is a recapitulation of respondents' responses to purchasing decisions at Abraham and Smith

Table 3. Recapitulation of Respondents' Responses to Purchasing Decisions in Abraham and Smith

\begin{tabular}{|c|c|c|c|c|c|c|c|c|}
\hline \multirow[b]{2}{*}{ No. } & \multirow[b]{2}{*}{ Statements } & \multirow[b]{2}{*}{ Weight } & \multirow[b]{2}{*}{$\mathrm{F}$} & \multirow[b]{2}{*}{ Score } & \multirow[b]{2}{*}{$\%$} & \multicolumn{3}{|c|}{ Total } \\
\hline & & & & & & Total score & $\begin{array}{l}\text { Ideal } \\
\text { score }\end{array}$ & $\%$ \\
\hline \multirow[t]{6}{*}{1.} & Purchases are made & 5 & 9 & 45 & 8,1 & \multirow{6}{*}{423} & \multirow{6}{*}{555} & \multirow{6}{*}{76,6} \\
\hline & based on a variety of & 4 & 73 & 292 & 65,8 & & & \\
\hline & food and beverages & 3 & 28 & 84 & 25,2 & & & \\
\hline & & 2 & 1 & 2 & 0,9 & & & \\
\hline & & 1 & - & - & - & & & \\
\hline & & Total & 111 & 423 & 100 & & & \\
\hline \multirow[t]{6}{*}{2.} & Purchases based on the & 5 & 8 & 40 & 7,2 & \multirow{6}{*}{397} & \multirow{6}{*}{555} & \multirow{6}{*}{71,5} \\
\hline & quality and taste of food & 4 & 52 & 208 & 46,8 & & & \\
\hline & and beverages & 3 & 47 & 141 & 42,3 & & & \\
\hline & & 2 & 4 & 8 & 3,6 & & & \\
\hline & & 1 & - & - & - & & & \\
\hline & & Total & 111 & 397 & 100 & & & \\
\hline \multirow[t]{6}{*}{3.} & \multirow{6}{*}{$\begin{array}{l}\text { Purchase based on the } \\
\text { attractiveness of the } \\
\text { product offered }\end{array}$} & 5 & 10 & 50 & 9 & \multirow{6}{*}{362} & \multirow{6}{*}{555} & \multirow{6}{*}{65,2} \\
\hline & & 4 & 41 & 164 & 36,9 & & & \\
\hline & & 3 & 31 & 93 & 27,9 & & & \\
\hline & & 2 & 26 & 52 & 46,8 & & & \\
\hline & & 1 & 3 & 3 & 2,7 & & & \\
\hline & & Total & 111 & 362 & 100 & & & \\
\hline \multirow[t]{6}{*}{4.} & \multirow{6}{*}{$\begin{array}{l}\text { Purchases based on } \\
\text { product popularity }\end{array}$} & 5 & 11 & 55 & 9,9 & \multirow{6}{*}{362} & \multirow{6}{*}{555} & \multirow{6}{*}{65,2} \\
\hline & & 4 & 38 & 152 & 34,2 & & & \\
\hline & & 3 & 35 & 105 & 31,5 & & & \\
\hline & & 2 & 23 & 46 & 20,7 & & & \\
\hline & & 1 & 4 & 4 & 3,6 & & & \\
\hline & & Total & 111 & 362 & 100 & & & \\
\hline 5. & Purchases based on & 5 & 9 & 45 & 8,1 & & & \\
\hline & product buying habits & 4 & 52 & 208 & 46,8 & & & \\
\hline & & 3 & 38 & 114 & 34,2 & 390 & 555 & 70,3 \\
\hline & & 2 & 11 & 22 & 9,9 & & & \\
\hline & & 1 & 1 & 1 & 0,9 & & & \\
\hline & & Total & 111 & 390 & 100 & & & \\
\hline 6. & Purchase based on & 5 & 8 & 40 & 7,2 & & & \\
\hline & strategic location & 4 & 28 & 112 & 25,2 & & & \\
\hline & & 3 & 61 & 183 & 55 & 361 & 555 & 65 \\
\hline & & 2 & 12 & 24 & 10,8 & & & \\
\hline & & 1 & 2 & 2 & 1,8 & & & \\
\hline & & Total & 111 & 361 & 100 & & & \\
\hline 7. & Purchase based on easy & 5 & 9 & 45 & 8,1 & & & \\
\hline & access & 4 & 29 & 116 & 26,1 & & & \\
\hline
\end{tabular}




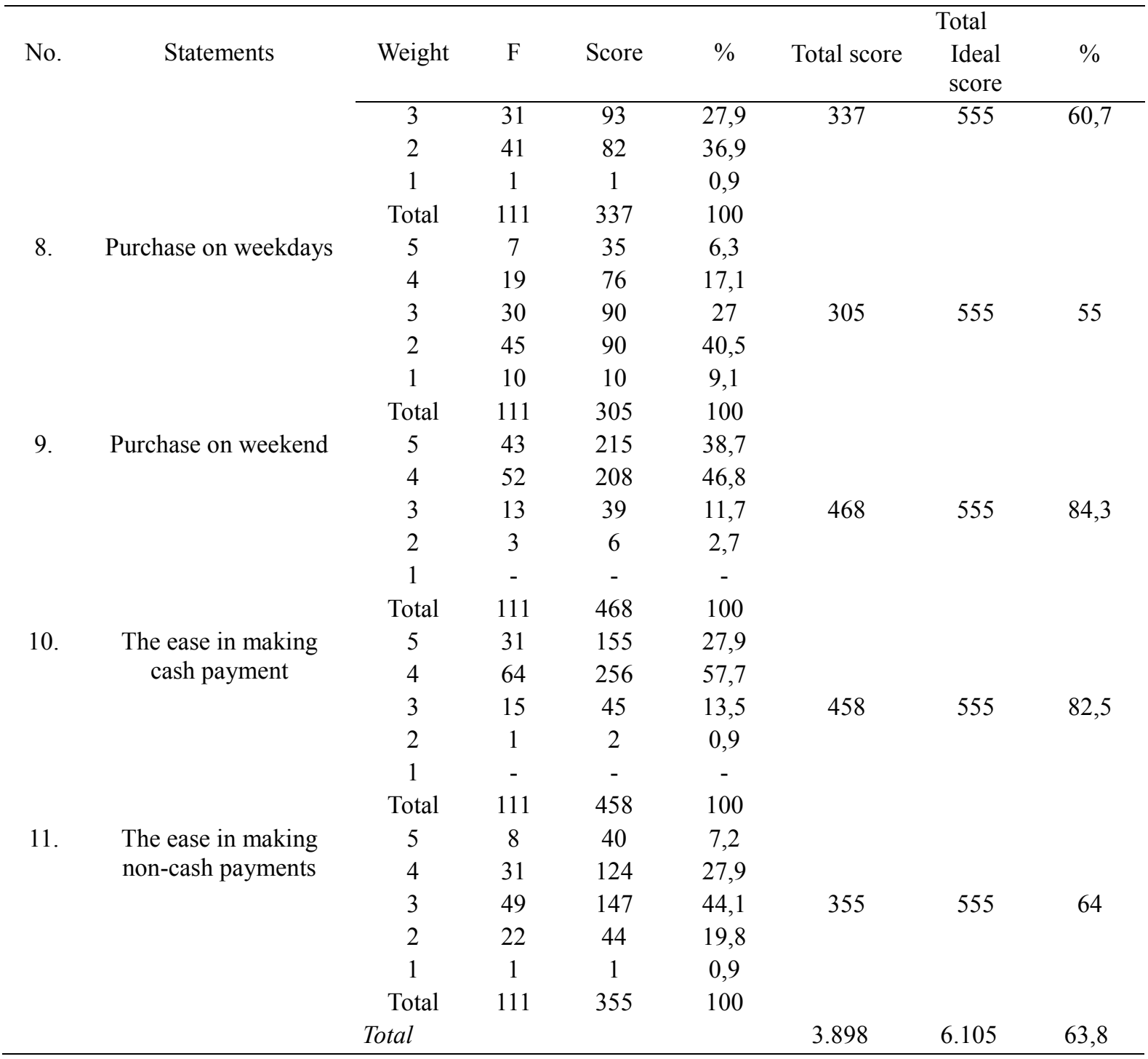

Source: Data processed by the author (2020)

Based on table 4.2, the response of the respondent that has the highest score is in the statement: "Purchases are made at the weekend", with a total score of 468 or $84.3 \%$. Meanwhile, the lowest score is in the statement "Purchases are made on weekdays" with a score of 305 or $55 \%$.

The total score of consumer purchasing decision is 3,898 . The score which is compared with the standard score criteria, and is obtained through the calculation of the ideal score and the smallest score through the standard score, resulting the continuum area that indicates the ideal area. It is obtained through the following formula.

Maximum index value $=$ Highest score $\mathrm{x}$ Number of statements $\mathrm{x}$ Number of respondents

$$
\begin{aligned}
& =5 \times 11 \times 111 \\
& =6.105
\end{aligned}
$$

Minimum index value $=$ Lowest score $\mathrm{x}$

Number of statements $\mathrm{x}$ Number of respondents

$$
\begin{aligned}
& =1 \times 11 \times 111 \\
& =1.221
\end{aligned}
$$

Variable level $=$ Maximum index value Minimum index value

$$
\begin{aligned}
& =6.105-1.221 \\
& =4.884
\end{aligned}
$$

Variable range $\quad=$ Variabel level : Number of interval classes

$$
\begin{aligned}
& =4.884: 5 \\
& =977
\end{aligned}
$$

Score percentage $\quad=$ (total score : maximum score)) x $100 \%$ 


$$
\begin{aligned}
& =(3.898: 6.105) \times 100 \% \\
& =63,8 \%
\end{aligned}
$$

The expected ideal score for respondents' answers regarding Consumer Purchasing Decisions in Abraham and Smith to 11 statements is 6.105. The calculation results obtained from a total score of 3,898 , with a percentage of $63.8 \%$, this indicates that Abraham and Smith's consumers made their own assesments. The following figure 4.2 is the result of Consumer Purchasing Decisions.

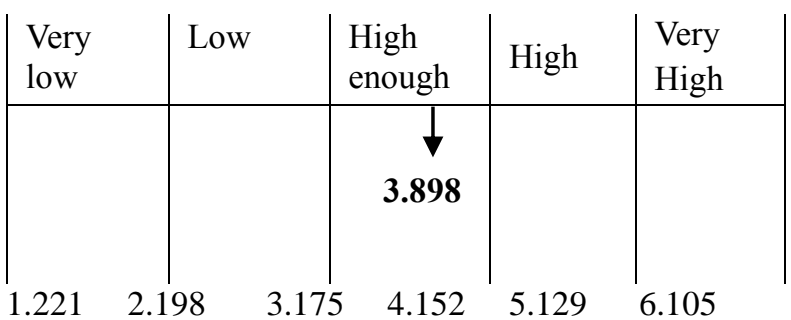

Figure 3 Continuum Line of Respondents' Responses to Consumer Purchasing Decisions in Abraham and Smith

The continuum line regarding Consumer Purchase Decision analysis, perceived by Abraham and Smith's consumers, falls into the "Fairly High" category. This shows that the Consumer Purchase Decision, get a fairly high evaluation from the consumers of Abraham and Smith.

\subsection{The Results of Multiple Linear} Regression Analysis

a. The constant is 0.438 , meaning that if the value of Product $\left(\mathrm{X}_{1}\right)$, Price $\left(\mathrm{X}_{2}\right)$, Place $\left(\mathrm{X}_{3}\right)$, Promotion $\left(\mathrm{X}_{4}\right)$, People $\left(\mathrm{X}_{5}\right)$, Physical Evidence $\left(\mathrm{X}_{6}\right)$ and Process $\left(\mathrm{X}_{7}\right)$ is 0 , the value of Consumer Purchase Decision $(\mathrm{Y})$ is 0.438 .

b. The product variable regression coefficient $\left(\mathrm{X}_{1}\right)$ is 0.302 , meaning that if the other independent variables are fixed in value, and the Product variable has increased by $1 \%$,
Consumer Purchase Decisions (Y) will increase by 0.302 . The coefficient is positive, meaning that there is a positive relationship between the product and the consumer's purchasing decision, the better the product the higher the consumer's purchasing decision.

c. The price variable regression coefficient $\left(\mathrm{X}_{2}\right)$ is 0.036 , meaning that if the other independent variables are fixed in value, and the price variable increases by $1 \%$, the Consumer Purchase Decision (Y) will increase by 0.036 . The coefficient is positive, meaning that there is a positive relationship between Price and Consumer Purchase Decisions, the more the price increases, the higher the Consumer Purchasing Decision.

d. The regression coefficient for Place $\left(\mathrm{X}_{3}\right)$ is 0.290 , meaning that if the other independent variables have a fixed value, and the Place variable has increased by 1\%, Consumer Purchasing Decisions (Y) will increase by 0.290 . The coefficient is positive, meaning that there is a positive relationship between Place and Consumer Purchase Decisions. The more the value of Places increases, the more the Consumer Purchase Decision increases.

e. Promotion regression coefficient $\left(\mathrm{X}_{4}\right)$ is 0.047 , meaning that if other independent variables are fixed in value, and the Promotion variable has increased by $1 \%$, Consumer Purchase Decisions (Y) will increase by 0.047 . The coefficient is positive, meaning that there is a positive relationship between Promotion and Consumer Purchase Decisions, the higher the Promotion the Consumer Purchasing Decisions.

f. The regression coefficient of People $\left(\mathrm{X}_{5}\right)$ is 0.005 , meaning that if other independent variables have a fixed 
value, and the People variable has increased by $1 \%$, Consumer Purchasing Decisions (Y) will increase by 0.005 . The coefficient is positive, meaning that there is a positive relationship between people and consumer purchasing decisions. the more the value of People increases, the higher the Consumer Purchasing Decision.

g. The regression coefficient of Physical Evidence $\left(\mathrm{X}_{6}\right)$ is 0.152 , meaning that if other independent variables have a fixed value, and the Physical Evidence variable has increased by $1 \%$, Consumer Purchase Decisions (Y) will increase by 0.152 . The coefficient is positive, meaning that there is a positive relationship between physical evidence and consumer purchasing decisions. The higher the value of Physical Evidence, the more the value of Consumer Purchasing Decisions.

h. The Process regression coefficient $\left(\mathrm{X}_{7}\right)$ is 0.023 , meaning that if the other independent variables are fixed in value, and the Process variable has increased by $1 \%$, the Consumer Purchase Decision (Y) will increase by 0.023 . The coefficient is positive, meaning that there is a positive relationship between the Process and Consumer Purchasing Decisions. The higher the value of the process, the more the value of consumer purchasing decisions.

4.5 The Results of Correlation Analysis and Coefficient of Determination

The correlation value (r) of Marketing Mix to Consumer Purchasing Decisions in Abraham and Smith is 0.765 . This means that the strength of the correlation between the Marketing Mix and the Consumer Purchasing Decisions is simultaneously included in the "Strong" category, because it is in the range of $0.60-0.799$. This indicates a strong level of relationship between
Marketing Mix and Consumer Purchasing Decisions.

Furthermore, the coefficient of determination $\left(\mathrm{R}^{2}\right)$ of 0.585 indicates that each dimension of Product (X1), Price (X2), Place (X3), Promotion (X4), People (X5), Physical Evidence (X6) and Process (X7) contributes $58.5 \%$ in the increase of Consumer Purchasing Decisions (Y). Meanwhile, the remaining $(41.5 \%)$ are factors that were not examined in this study.

\subsection{F-Test Results}

The obtained Fcount is 20,763. This value is the Fcount value of, the correlation between the Marketing Mix variable, the overall Consumer Purchase Decision with the probability level of Sig. 0,000. Value of Fcount> Ftable $(20,763>2.11)$ then Ho is rejected. Because Fcount> Ftable (20,763> 2.11), Ho is rejected and $\mathrm{Ha}$ is accepted, meaning that there is a significant influence between the Marketing Mix on Consumer Purchasing Decisions. Thus, it can be concluded that the Marketing Mix influences the Consumer Purchasing Decision in Abraham and Smith.

\subsection{T-Test Results}

a. There is a significant influence between Product variables on Consumer Purchasing Decisions, because the value of $t$ count is 3,939> 1,291 and a significance value of $0,000<0.05$, so that Ho is rejected and Ha is accepted, meaning that partially there is a significant effect between Products and Consumer Purchasing Decisions.

b. There is no significant influence between Price variables on Consumer Purchasing Decisions, because the tvalue is $0.579<1.291$ and the significance value is $0.564>0.05$ so that Ho is accepted and Ha is rejected, meaning that partially there is no significant effect between Price and Consumer Purchase Decisions.

c. There is a significant influence 
between the Place variable on Consumer Purchasing Decisions, because the $t$ value is $4.025>1.291$ and the significance value is 0.000 $<0.05$ so that $\mathrm{Ho}$ is rejected and $\mathrm{Ha}$ is accepted, meaning that partially there is a significant influence between Place and Consumer Purchasing Decisions.

d. There is no significant influence between the Promotion variable on Consumer Purchasing Decisions, because the $\mathrm{t}$ value is $0.946<1.291$ and the significance value is $0.346>$ 0.05 so that $\mathrm{Ho}$ is accepted and $\mathrm{Ha}$ is rejected, meaning that partially there is no significant effect between Promotion and Consumer Purchasing Decisions.

e. There is no significant influence between the People variable on the Consumer Purchase Decision, because the $\mathrm{t}$ value is $0.072<1.291$ and the significance value is $0.943>0.05$ so that Ho is accepted and $\mathrm{Ha}$ is rejected, meaning that partially there is no significant effect between People with Consumer Purchasing Decisions.

f. There is a significant influence between the Physical Evidence variable on Consumer Purchasing Decisions, because the $\mathrm{t}$ value is 2.046> 1.291 and the significance value is $0.043<0.05$ so that $\mathrm{Ho}$ is rejected and $\mathrm{Ha}$ is accepted, meaning that partially there is a significant effect between Physical Evidence and Consumer Purchasing Decisions.

g. There is no significant influence between Process variables on Consumer Purchasing Decisions, because the $t$ value is $0.293<1.291$ and the significance value is $0.770>$ 0.05 so that Ho is accepted and $\mathrm{Ha}$ is rejected, meaning that partially there is no significant effect between Process and Consumer Purchasing Decisions.

Based on the variables above, only
Product, Place, and Physical Evidence that have significant effects on purchasing decisions.

\subsection{Discussion}

Each aspect of the Marketing Mix has its own elements, namely:

a. A product is something that can be offered to the market to meet the needs and desires of consumers. Abraham and Smith has its mainstay product namely Spiritual Coldbrew White Coffee.

b. Price is an amount of money used as a medium of exchange between goods or services. Abraham and Smith set the price for the products they sell, with a price range of Rp. 18,000 - Rp. 139,000.

c. Place is a location where the company carries out the operational activities. Abraham and Smith are located at Jalan Tamblong Dalam No.2 Kb. Pisang, Sumur Bandung, Bandung City, West Java.

d. Promotion is a form of marketing communication. It can be marketing activities, such as spreading information to target markets about the companies and their products. Abraham and Smith promoted their company on social media, such as Instagram with the account name: @abrahamandsmith.

e. People or employee serves or plans services to consumers. This People or employee functions as a service provider, which affects the quality of the services provided. Every People who will provide these services must be selected, trained, and motivated. Abraham and Smith's employees received training before they start working. However, is no binding SOP.

f. Physical Evidence is a physical style or appearance, as well as other elements of experience that are determined by consumers, when enjoying services and products in a 
certain place. Abraham and Smith carries a rustic concept, has a toilet and prayer room, and there are several entertainment facilities for consumers.

g. Process is a combination of all activities. Process in services is a major factor in the marketing mix of services, as consumers will often perceive the service delivery system as part of the service itself. The process in Abraham and Smith is the similar to the cafe process in general, such as the order process, payment transaction processing, etc.

\section{Conclusions}

Through descriptive and verificative multiple regression analysis of the marketing mix and consumer purchasing decisions to Abraham and Smith consumers, it can be concluded that:

a. Products in the marketing mix partially have a significant effect. This is evidenced by the significance value obtained at $0.000<0.5$ and $t$ count 3.939> 1.291. This means that the product variables in the marketing mix have a positive and significant effect on Abraham and Smith's consumer purchasing.

b. Partially, the price in the marketing mix has no significant effect. This is evidenced by the obtained significance value of $0.564>0.05$ and $t$ count $0.579<1.291$. This means that the price variable in the marketing mix has no effect on Abraham and Smith's consumer purchasing decisions.

c. Place in the marketing mix partially has a significant effect. This is evidenced by the significance value obtained at $0.000<0.05$ and $\mathrm{t}$ count 4.025> 1.291. This means that the place variable in the marketing mix has a positive and significant effect on Abraham and Smith's consumer purchasing decisions.

d. Promotion in the marketing mix partially has no significant effect. This is evidenced by the significance value obtained at $0.346>0.05$ and $t$ count $0.946<1.291$. This means that the promotion variable in the marketing mix has no effect on Abraham and Smith's consumer purchasing decisions.

e. People in the marketing mix have no significant influence partially. This is evidenced by the significance value obtained at $0.943>0.05$ and $t$ count $0.072<1.291$. That is, the People variable in the marketing mix has no effect on Abraham and Smith's consumer purchasing decisions.

f. Physical evidence in the marketing mix partially has a significant effect. This is evidenced by the significance value obtained at $0.043<0.05$ and $\mathrm{t}$ count 2.046> 1.291. This means that the physical evidence variable in the marketing mix has a positive and significant effect on consumer purchasing decisions.

g. The process in the marketing mix partially has no significant effect. This is evidenced by the significance value obtained at 0.770>0.05 and t count $0.293<1.291$. This means that the process variables in the marketing mix have no effect on Abraham and Smith's consumer purchasing decisions.

\section{Acknowledgment}

Based on the research conducted by the authors, the suggestions that can be given are as follows:

a. This research discovers that Abraham and Smith's Promotion gets the lowest score. For example, promotion on the Abraham and Smith's website is still lacking. For this reason, Abraham and Smith is expected to develop promotions via the website as an addition to the promotion media used.

b. Based on observation, several tables 
are heavily covered in dust. For this reason, it is expected that Abraham and Smith to pay more attention to the cleanliness of the unused tables, not only the tables that are already used by consumers.

c. Based on observation, the dish that was served looked less attractive. Therefore, it is suggested that Abraham and Smith's improve the attractiveness of the dishes served, with references to the latest trend of food styling.

d. Based on observations, some employees appear untidy with their attires. For this reason, Abraham and Smith's is expected to pay more attention to the appearance of their employees.

e. Based on observation, the consumers enjoyed the place and atmosphere of Abraham and Smith. Therefore, it is expected that Abraham and Smith to maintain the appearance of the interior design and layout of the place and make some improvements.

\section{References}

Amos Neolaka. (2014). Metode Penelitian dan Statistik. Bandung: Remaja Rosdakarya.

Arief, A. R. (2005). Pengantar Ilmu Perhotelan dan Restoran. Yogyakarta: Graha Ilmu.

A.Yoeti, Oka. (2005). Perencanaan Strategi Pemasaran Daerah Tujuan Wisata. Jakarta: PT Pradnya Paramita.

Bagyono. (2007). Pariwisata dan Perhotelan. Bandung: Alfabeta

Bernadette, J. (2013). Promosi, Distribusi, Harga Pengaruhnya Terhadap Keputusan Pembelian Rokok Surya Promild.

Engel, J. F., G. Blackwell. (2004). Perilaku Konsumen. Jakarta: Binarupa Aksara.

Hurriyati, R. (2010). Bauran Pemasaran dan Loyalitas Konsumen. Bandung: Alfabeta.
Indrayana. (2006). Desain Interior Restoran Arma di Ubud Bali. Jakarta: PT Elex Media Komputindo.

Koko, I. (2010). Potensi Objek Wisata Sebagai Daya Tarik Wisata.Yogyakarta: Kertas Karya.

Kotler. (2007). Manajemen Pemasaran (12th ed.). Jakarta: PT Indeks.

Kotler. (2009). Manajemen Pemasaran (13th ed.). Jakarta: Erlangga.a

Lupiyoadi, R. (2013). Manajemen Pemasaran Jasa Berbasis Kompetensi (Edisi 3). Jakarta: Salemba Empat.

Marsum. (2005). Restoran dan Segala Permasalahannya. Yogyakarta: Andi.

Narimawati, Umi. (2010) Metodologi Penelitian : Dasar Penyusun Penelitian Ekonomi. Jakarta : Genesis.

Noor, J. (2011). Metodologi Penelitian: Skripsi, Tesis, Disertasi, dan Karya Ilmiah. Jakarta: Kencana.

Rachmawati, R. (2011). Peranan Bauran Pemasaran (Marketing Mix) terhadap Peningkatan Penjualan (Sebuah Kajian terhadap Bisnis Restoran).

Santoso, D, T, T. (2013). Pengaruh Faktor Budaya, Faktor Sosial, Faktor Pribadi, Dan Faktor Psikologi Terhadap Keputusan Pembelian Konsumen Dalam Memilih Produk Operator Seluler Indosat-M3 Di Kecamatan Pringapus Kab. Semarang.

Setiadi, J. Nugroho. (2003). Perilaku Konsumen: Konsep dan Implikasi untuk Strategi dan Penelitian Pemasaran. Jakarta: Prenada Media.

Sugiyono. (2008). Metode Penelitian Kuantitatif , Kualitatif dan R \& D. Bandung: Alfabeta.

Jilly Bernadette, Ekonomi, F., Manajemen, J., Sam, U., \& Manado, R. (n.d.). No Title. 1(4), 95-104.

Tjiptono, F. (2000). Manajemen Jasa (2nd ed.). Yogyakarta: Andi Offset.

Tjiptono, F. (2007). Strategi Pemasaran (1st ed.). Yogyakarta: Andi Offset.

Undang-Undang Nomor 9 Tahun 1990.

Wardiyanta. (2006). Metode Penelitian Pariwisata. Yogyakarta : Andi 
